\title{
PRAVILA EUROPSKE UNIJE O TRŽIŠNOM NATJECANJU I DRŽAVNIM POTPORAMA I DOPUNSKO ZDRAVSTVENO OSIGURANJE U REPUBLICI HRVATSKOJ: KRIVO SRASTANJE?
}

Sažetak: $\quad$ Pravila o tržišnom natjecanju i državnim potporama nisu primjenjiva na obvezno zdravstveno osiguranje u Republici Hrvatskoj, budući da ono ne predstavlja gospodarsku aktivnost u smislu prava Europske unije. S druge strane, dopunsko zdravstveno osiguranje, kakvo postoji u Republici Hrvatskoj, predstavlja gospodarsku aktivnost jer u ovom području u Hrvatskoj nedvojbeno postoji stvarno tržišno natjecanje između poduzetnika. U opisanoj situaciji postojanja natjecanja na tržištu dopunskog zdravstvenog osiguranja, može se ustvrditi da posebna pravila koja se primjenjuju na Hrvatski zavod za zdravstveno osiguranje (HZZO) dovode do njegova povlaštenog položaja u odnosu na društva za osiguranje na koja se ta pravila ne primjenjuju. Navedeni povlašteni položaj dodatno je ojačan činjenicom da HZZO kao zakonski monopolist obveznog zdravstvenog osiguranja koristi svoju infrastrukturu u sferi dopunskog zdravstvenog osiguranja, što mu omogućuje smanjenje troškova u odnosu na društva za osiguranje koja nemaju takvu povlasticu.

Rješenje za navedenu situaciju može biti osnivanje posebnog subjekta od strane države koji bi obavljao djelatnost dopunskog zdravstvenog osiguranja. Ovakav subjekt morao bi sklapati police sa svim osiguranicima s jednakom premijom $i$ zajamčenim jednakim paketom usluga bez obzira na njihovu dob, spol $i$ zdravstveno stanje. Kako bi se spriječilo da privatni konkurenti, preuzimanjem isključivo osiguranika s povoljnijim profilom rizika, ugroze funkcioniranje usluge od općeg interesa, oni bi morali, prema jasno i objektivno određenim kriterijima,

\footnotetext{
* Dr. sc. Tomislav Sokol, docent Hrvatskog katoličkog sveučilišta u Zagrebu, Ilica 242, 10000 Zagreb i profesor na Zagrebačkoj školi ekonomije i managementa, Vukasovićeva ulica 1, 10000 Zagreb. E-adresa: tsokol12@gmail.com. ORCID: https://orcid. org/0000-0002-3592-2967.

** Dr. sc. Frane Staničić, izvanredni profesor Pravnog fakulteta Sveučilišta u Zagrebu, Trg Republike Hrvatske 14, 10000 Zagreb. E-adresa: frane.stanicic@pravo.hr. ORCID: https://orcid.org/0000-0001-8304-7901.
} 
transferirati sredstva javnom subjektu koji bi, za razliku od njih, morao sklapati ugovore s osiguranicima svih profila, uključujući i one s nepovoljnijim profilom rizika od tržišnog, poput starijih osoba i kroničnih bolesnika. Na ovaj način, pomirila bi se potreba očuvanja usluge od općeg interesa, odnosno dostupnosti dopunskog zdravstvenog osiguranja svim osobama uključujući one sa slabijim profilom rizika, s natjecanjem na unutarnjem tržištu Europske unije.

Ključne riječi: dopunsko zdravstveno osiguranje, državne potpore, proporcionalnost, tržišno natjecanje, usluge od općeg gospodarskog interesa

\section{UVOD}

Zdravstvena zaštita predstavlja primarnu nadležnost država članica Europske unije. Članak 168. Ugovora o funkcioniranju Europske unije ${ }^{1}$ propisano je da djelovanje EU-a u sferi zdravstva dopunjuje politike država članica u smislu uklanjanja izvora opasnosti za zdravlje ljudi, sprečavanja tjelesnih i duševnih bolesti i oboljenja te poboljšanja javnog zdravlja. Pri svome djelovanju EU mora poštovati odgovornost država članica za utvrđivanje vlastite zdravstvene politike te organizaciju i pružanje zdravstvene zaštite. Na državama članicama leži odgovornost za upravljanje zdravstvenim sustavom te raspodjelu dodijeljenih im sredstava.

S druge strane, osim dopunjavanja politike država članica u području javnog zdravstva, Unija na nacionalne zdravstvene sustave utječe i putem vlastitih tržišnih pravila o slobodi kretanja te tržišnom natjecanju i (zabranjenim) državnim potporama. To je vidljivo u području prekograničnih zdravstvenih usluga ${ }^{2}$ ali i usklađenosti nacionalnih propisa o obveznom i dopunskom zdravstvenom osiguranju s pravilima EU-a o zaštiti tržišnog natjecanja, posebno propisima o zabrani zlouporabe vladajućeg položaja i državnim potporama.

Cilj je ovog rada analizirati regulatorni okvir Europske unije u sferi pravila o zaštiti tržišnog natjecanja i državnih potpora te utvrditi jesu li hrvatski propisi koji uređuju dopunsko zdravstveno osiguranje usklađeni s navedenim okvirom. Poseban naglasak stavljen je na primjenjivost europskih tržišnih pravila na dopunsko zdravstveno osiguranje kao djelatnost od općeg interesa te ulogu Hrvatskog zavoda za zdravstveno osiguranje (HZZO) kao ustanove koja istovremeno provodi obvezno i dopunsko zdravstveno osiguranje u Republici Hrvatskoj. ${ }^{3}$

U prvom poglavlju nakon uvoda prikazuje se europski pravni okvir u sferi zaštite tržišnog natjecanja i državnih potpora te njegov utjecaj na dopunsko zdravstveno osiguranje. Prvo se analizira primjenjivost europskih pravila u ovome području, a zatim utjecaj pravila o zlouporabi vladajućeg položaja na tržištu na nacionalnu regulativu dopunskog osiguranja. U idućim poglav-

1 Ugovor o funkcioniranju Europske unije (pročišćena verzija) (2016) OJ C202/47.

2 Vidi, primjerice, predmet C-158/96 Raymond Kohll v Union des caisses de maladie (1998) ECR I-01931. O načelu proporcionalnosti vidi, primjerice, Vassilis G Hatzopoulos, 'Killing National Health and Insurance Systems but Healing Patients? The European Market for Health Care Services after the Judgements of the ECJ in Vanbraekel and Peerbooms' (2002) 39 CML Rev 683.

3 Vidi čl. 3. Zakona o obveznom zdravstvenom osiguranju, NN 80/2013, 137/2013, 98/2019 i čl. 11.-16. Zakona o dobrovoljnom zdravstvenom osiguranju, NN 85/2006, 150/2008, 71/2010, 53/2020. 
ljima prikazuje se relevantni hrvatski pravni okvir koji uređuje dobrovoljno zdravstveno osiguranje, analizira njegova usklađenost s europskim pravilima te ukazuje na problematične odredbe koje se mogu tumačiti kao protivne Ugovoru o funkcioniranju Europske unije. Na kraju, predlažu se konkretna rješenja kako hrvatski pravni okvir uskladiti s europskim, uz zaštitu općeg interesa radi kojeg je uspostavljeno dopunsko zdravstveno osiguranje u Republici Hrvatskoj.

\section{EUROPSKI PRAVNI OKVIR}

Pravila Europske unije o tržišnom natjecanju i zabranjenim državnim potporama primjenjiva su na poduzetnike koji obavljaju određenu gospodarsku aktivnost bez obzira na način financiranja i jesu li u državnom ili privatnom vlasništvu. ${ }^{4}$ Navedenu definiciju postavio je Sud Europske unije početkom devedesetih godina 20. stoljeća. Sud naglasak stavlja na djelatnost koju subjekt obavlja, uzimajući u obzir niz relevantnih činjenica, što predstavlja funkcionalni pristup definiranju pojma poduzetnika u europskom pravu. ${ }^{5}$

Više je kriterija koje Sud uzima u obzir pri određivanju je li riječ u nekoj situaciji o gospodarskoj aktivnosti ili ne. U tom smislu posebnu ulogu igraju kriteriji solidarnosti, postojanja državne kontrole nad djelatnosti subjekta, ostvarivanja dobiti i funkcije odnosno svrhe subjekta. ${ }^{6}$ Pri tome je važno napomenuti da prisutnost ni jednog od navedenih kriterija nije sama po sebi dovoljna da se određeni subjekt isključi iz područja primjene tržišnih pravila EU-a, već je potrebno analizirati specifičnosti svakog pojedinog slučaja kako bi se utvrdilo je li riječ o gospodarskoj djelatnosti ili ne. ${ }^{7}$

Sve navedeno primjenjivo je u kontekstu zdravstva, odnosno zdravstvenog osiguranja. Ovdje je posebno važan kriterij solidarnosti. U tom smislu, način propisivanja doprinosa za zdravstveno osiguranje u velikoj mjeri određuje hoće li tržišna pravila Unije biti primjenjiva na djelatnost zdravstvenog osigurateljskog fonda ili ne. Kada postoji više takvih fondova koji imaju zakonsku obvezu pružati identični paket usluga bez obzira na iznos doprinosa plaćen od strane osiguranika, te kada iznos doprinosa ne ovisi o riziku, nije riječ o gospodarskoj djelat-

4 Vidi predmet C-41/90 Klaus Höfner and Fritz Elser v Macrotron GmbH (1991) ECR I-1979, para 21. Vidi i Christopher Townley, 'The Concept of an 'Undertaking': The Boundaries of the Corporation - A Discussion of Agency, Employees and Subsidiaries' u Giuliano Amato i Claus-Dieter Ehlermann (ur), EC Competition Law: A Critical Assesment (Hart Publishing 2007) 23 i Okeoghene Odudu, 'Are State-owned health-care providers undertakings subject to competition law? ' (2011) 48 European Competition Law Review 231.

5 Vidi Mladen Cerovac, 'Pojam poduzetnika u pravu tržišnog natjecanja' (2005) Hrvatska pravna revija 60, Ana Poščić, 'Pojam poduzetnika u europskom pravu tržišnog natjecanja' (2008) 29 Zbornik Pravnog fakulteta Sveučilišta u Rijeci 917 te Tomislav Sokol i Frane Staničić, 'Usluge od općeg gospodarskog interesa u pravu Europske unije i hrvatski regulatorni okvir u odabranim upravnim područjima' (2019) 69 Zbornik Pravnog fakulteta u Zagrebu 803, 807-810. Vidi i Obavijest Komisije o pojmu državne potpore iz članka 107. stavka 1. Ugovora o funkcioniranju Europske unije (2016) OJ C262/01 iz koje proizlazi da su kriteriji isti u kontekstu državnih potpora i prava tržišnog natjecanja.

6 Vidi Tomislav Sokol i Frane Staničić, 'Pravni položaj Katoličke Crkve kao gospodarskog subjekta u pravu Europske unije i hrvatskom pravu' (2018) 68 Zbornik Pravnog fakulteta u Zagrebu 31, 34-37.

7 Usporedi, primjerice, spojene predmete C-159/91 i C-160/91 Christian Poucet v Assurances Générales de France and Caisse Mutuelle Régionale du Languedoc-Roussillon (1993) ECR I-637, para 8 i predmet C-244/94 Fédération Française des Sociétés d'Assurance, Société Paternelle-Vie, Union des Assurances de Paris-Vie and Caisse d'Assurance et de Prévoyance Mutuelle des Agriculteurs v Ministère de l'Agriculture et de la Pêche (1995) ECR I-4013, paras 17-20. 
nosti u smislu pravila EU-a o zaštiti tržišnog natjecanja. ${ }^{8}$ U kontekstu pružatelja zdravstvene zaštite, bolnice kao sastavni dio besplatnog zdravstvenog sustava utemeljenog na načelu solidarnosti, koji se pretežno financira od strane države, ne smatraju se poduzetnicima te na njih nisu primjenjiva tržišna pravila Unije. ${ }^{9}$

Sveukupno se može zaključiti da državna vlast ima pravo vlastitom regulativom određena područja isključiti s tržišta, bilo uspostavom zakonskom monopola, bilo stvaranjem pravnog okvira koji natjecanje s javnim subjektima čini nemogućim, odnosno neisplativim. Ondje gdje postoji natjecanje i subjekti snose poslovni rizik tog natjecanja, možemo govoriti o gospodarskoj djelatnosti na koju su primjenjiva tržišna pravila Europske unije. ${ }^{10} \mathrm{Kad}$ u navedene okvire stavimo zdravstveno osiguranje u Republici Hrvatskoj, možemo zaključiti da obvezno osiguranje koje provodi HZZO ne predstavlja gospodarsku djelatnost koja je obuhvaćena europskim pravilima o tržišnom natjecanju. Ono je utemeljeno na načelu solidarnosti budući da se opseg prava iz obveznog zdravstvenog osiguranja osigurava svim osiguranim osobama pod jednakim uvjetima, bez obzira na to plaćaju li doprinose (i koji iznos) ili ne. Također, iznos doprinosa određuje se kao postotak od dohotka obveznika plaćanja doprinosa, a ne prema riziku. ${ }^{11}$ Drugačija je situacija u sferi dobrovoljnog dopunskog zdravstvenog osiguranja, o čemu će više biti riječi u nastavku. ${ }^{12}$

Pored činjenice da pravila o tržišnim natjecanju i državnim potporama nisu primjenjiva na sustav obveznog zdravstvenog osiguranja, može se dogoditi da pravila o zabranjenim državnim potporama ne budu primjenjiva na dobrovoljno dopunsko zdravstveno osiguranje. Riječ je o slučajevima u kojima se ova vrsta zdravstvenog osiguranja smatra uslugom od općeg gospodarskog interesa na koju pravila o državnim potporama nisu primjenjiva ako su zadovoljeni uvjeti koje je definirao Sud Europske unije u predmetu Altmark. Prema prvom uvjetu, poduzetniku korisniku određene naknade dodijeljenu od strane javne vlasti mora biti povjereno izvršavanje obveza javne usluge, koje moraju biti jasno određene. Prema drugom uvjetu, mjerila na temelju kojih se izračunava navedena naknada moraju biti prethodno određena na objektivan i transparentan način. Prema trećem uvjetu, iznos ove naknade ne smije premašiti iznos koji je potreban za pokrivanje svih ili dijela troškova koji su nastali izvršavanjem obveza pružanja javne usluge, uzimajući u obzir prihode i razumnu dobit korisnika naknade. Prema četvrtom uvjetu, ako izbor poduzetnika kojem se povjerava izvršavanje obveza javne usluge nije obav-

8 Vidi, primjerice, spojene predmete C-264/01, C-306/01, C-354/01 i C-355/01 AOK Bundesverband, Bundesverband der Betriebskrankenkassen (BKK), Bundesverband der Innungskrankenkassen, Bundesverband der landwirtschaftlichen Krankenkassen, Verband der Angestelltenkrankenkassen eV, Verband der Arbeiter-Ersatzkassen, Bundesknappschaft and See-Krankenkasse v IchthyolGesellschaft Cordes, Hermani \& Co. (C-264/01), Mundipharma GmbH (C-306/01), Gödecke GmbH (C-354/01) and Intersan, Institut für pharmazeutische und klinische Forschung GmbH (C-355/01) (2004) ECR I-2493, para 52 i predmet C-437/09 AG2R Prévoyance v Beaudout Père et Fils SARL (2011) ECR I-973, paras 48-50.

9 Vidi predmet T-319/99 Federación Nacional de Empresas de Instrumentación Científica, Médica, Técnica y Dental (FENIN) v Commission of the European Communities (2003) ECR II-357, paras 35-44 i predmet C-205/03 P Federación Española de Empresas de Tecnología Sanitaria (FENIN) v Commission of the European Communities (2006) ECR I-6295 te Sokol, Staničić (n 4) 808. $\mathrm{Na}$ ovu temu vidi i, primjerice, Victoria Louri, 'The FENIN Judgment: The Notion of Undertaking and Purchasing Activity' (2005) 32 Legal Issues of Economic Integration 87. Treba navesti da se stranke u postupku nisu na vrijeme pozvale na to da su španjolske bolnice u određenim situacijama ipak pružale i naplaćivale privatne zdravstvene usluge za osobe koje nisu obuhvaćene nacionalnim zdravstvenim sustavom (kao što su strani turisti), što je svakako moglo utjecati na odluku Suda. I-6451, para 76. 
ljen provođenjem postupka javne nabave, iznos naknade mora se odrediti na temelju analize troškova koje bi tipični poduzetnik, odgovarajuće opremljen sredstvima koja su potrebna za ispunjavanje zahtjeva javne usluge i dobro vođen, imao pri izvršavanju navedenih obveza. ${ }^{13}$

U kontekstu dobrovoljnog zdravstvenog osiguranja, opisani uvjeti izuzetno su bitni jer mogu dovesti do izuzimanja navedenog sektora iz područja primjene europskih propisa o državnim potporama. Praktičan primjer za to može biti predmet BUPA. U navedenom slučaju, riječ je bila o irskom sustavu dopunskog zdravstvenog osiguranja. U Irskoj je u to vrijeme oko 50\% stanovništva imalo status osiguranika u zdravstvenom osiguranju koje su pružali privatni osiguratelji. Razlog tome dijelom je bio u činjenici da je dio stanovnika imao pravo na pun opseg zdravstvene zaštite pokriven od strane Irskog zavoda za zdravstveno osiguranje financiranog primarno iz poreza u sustavu koji je otprilike odgovarao hrvatskom obveznom zdravstvenom osiguranju (ovisno o imovinskom cenzusu), dok su ostali morali plaćati troškove iz vlastitih sredstava. Privatno zdravstveno osiguranje ustanovljeno je dijelom radi snošenja navedenih troškova, a dijelom kao alternativa javnom sustavu te je u tu svrhu država osnovala vlastitu ustanovu (Voluntary Health Insurance Board - VHI) kao osiguratelja. Nakon liberalizacije tržišta, omogućena je privatna konkurencija, no da bi se spriječilo da privatni osiguratelji osiguravaju samo mlade i zdrave osobe s povoljnim profilom rizika, ustanovljen je sustav ujednačavanja rizika. Prema ovom sustavu, osiguratelji s profilom rizika koji je bio povoljniji od prosječnog tržišnog profila morali su plaćati određenu naknadu javnom tijelu (Health Insurance Authority - HIA) koje je transferiralo navedena sredstva onim osigurateljima koji su imali lošiji profil rizika od prosječnog tržišnog profila. U praksi, navedene uplate primao je prvenstveno VHI koji je, kao javna ustanova, morao sklapati ugovore s osiguranicima svih profila, uključujući i one s nepovoljnijim profilom rizika od tržišnog (starije osobe, kronični bolesnici itd.). ${ }^{14}$

Privatni osiguratelji su u ovom slučaju tvrdili da ne postoji obveza izvršavanja javne usluge, odnosno usluge od općeg gospodarskog interesa, već da je riječ o tržištu podložnom normalnom tržišnom regulatornom okviru na kojem sustav ujednačavanja rizika predstavlja zabranjenu državnu potporu određenim osigurateljima, konkretno javnom osiguratelju (VHI). Navedena argumentacija nije prihvaćena od strane Suda, koji je zaključio da je riječ o usluzi od općeg gospodarskog interesa u smislu presude u predmetu Altmark, na koju pravila o zabranjenim državnim potporama nisu primjenjiva. Odluka Suda utemeljena je na tome da je postojala obveza sklapanja ugovora sa svakom zainteresiranom osobom, bez obzira na njezino zdravstveno stanje, dob i spol te na činjenici da su premije bile identične bez obzira na zdravstveno stanje osiguranika. Što se tiče sustava ujednačavanja rizika, on je bio proporcionalan svojoj svrsi, budući da je transfer sredstava sveden na najmanju mjeru potrebnu da pružatelj usluge od općeg gospodarskog interesa (VHI) može doista i ispuniti obvezu pružanja navedene usluge. $^{15}$

13 Vidi predmet C-280/00 Altmark Trans GmbH and Regierungspräsidium Magdeburg v Nahverkehrsgesellschaft Altmark GmbH, and Oberbundesanwalt beim Bundesverwaltungsgericht (2003) ECR I-7747, paras 88-93 te Mirko Klarić i Mia Nikolić, 'Ustrojstvo javnih službi u Europskom pravnom poretku' (2011) 48 Zbornik radova Pravnog fakulteta u Splitu 89, 99. Vidi i Wolf Sauter, 'Services of general economic interest and universal service in EU law' (2008) TILEC Discussion Paper.

14 Vidi predmet T-289/03 British United Provident Association Ltd (BUPA), BUPA Insurance Ltd and BUPA Ireland Ltd $v$ Commission of the European Communitie (2008) ECR II-81.

15 Vidi BUPA (n 13) paras 174-258. Vidi i Department of Health and Children (Ireland), Report of the Expert Group on Resource Allocation and Financing in the Health Sector (Government Publications 2010) 47. Vidi takoder i Piet Calcoen i Wynand van de 
Dakle, mada se dobrovoljno zdravstveno osiguranje može odvijati na tržištu i predstavljati gospodarsku aktivnost u smislu europskih tržišnih pravila (za razliku od obveznog zdravstvenog osiguranja), država članica ima pravo intervenirati na takvom tržištu da bi omogućila pružanje usluge od općeg gospodarskog interesa onima kojima je ona potrebna. Takva intervencija međutim mora biti nužna kako bi se postigao navedeni cilj (test proporcionalnosti), a kriteriji za transfer sredstava onim subjektima koji pružaju ovakvu uslugu moraju biti jasno i transparentno definirani.

Iz prethodne analize proizlazi da sustav obveznog zdravstvenog osiguranja utemeljen na načelu solidarnosti, kojeg provodi državni monopolist te u kojem opseg zdravstvene zaštite nije povezan s iznosom uplaćenih doprinosa, niti se taj iznos određuje prema profilu rizika osiguranika, ne predstavlja gospodarsku aktivnost te zbog toga nije obuhvaćen pravilima Europske unije o tržišnom natjecanju i zabranjenim državnim potporama. Sustav dobrovoljnog zdravstvenog osiguranja neće biti obuhvaćen pravilima o državnim potporama ako on predstavlja uslugu od općeg gospodarskog interesa koju pruža javni subjekt koji ima obvezu sklapanja ugovora sa svakom zainteresiranom osobom, bez obzira na njezino zdravstveno stanje, dob i spol, s premijama koje su identične bez obzira na zdravstveno stanje osiguranika. U potonjem slučaju država može intervenirati kroz sustav ujednačavanja rizika koji je proporcionalan svojoj svrsi, s jasno i transparentno određenim kriterijima za transfer sredstava onim subjektima koji pružaju ovakvu uslugu.

Problem može nastati u situaciji u kojoj u nekoj djelatnosti nema tržišnog natjecanja budući da određeni subjekt ima zakonski monopol na obavljanje te djelatnosti, a koristi takav položaj da u nekoj drugoj djelatnosti ostvari i zlouporabi vladajući položaj, što je zabranjeno čl. 102. Ugovora o funkcioniranju Europske unije. Riječ je o slučajevima unakrsnih subvencija. Europska komisija ovaj je pojam prvi put definirala 1998. u poštanskom sektoru, kao situaciju u kojoj poduzetnik određuje ili snosi ukupni iznos ili dio troškova od svoje aktivnosti na jednom tržištu u proizvodnom ili zemljopisnom smislu (rezervirana djelatnost) za svoju djelatnost na drugom tržištu u proizvodnom ili zemljopisnom smislu. Unakrsno financiranje može narušiti tržišno natjecanje u određenoj djelatnosti te dovesti do suboptimalne situacije u smislu učinkovitosti budući da se subjekt koji sudjeluje na tržištu koristi unakrsnim subvencioniranjem i na taj način uzrokuje nepravedno tržišno natjecanje. Ovakvo financiranje nije problematično ako su troškovi rezerviranih djelatnosti subjekta financirani prihodima nastalim iz pružanja nekih drugih rezerviranih usluga, budući da u tom slučaju nije moguće tržišno natjecanje. Spomenuti oblik financiranja može ponekad čak biti i nužan, da bi se omogućilo ispunjavanje obveze pružanja usluga od općeg interesa pod jednakim uvjetima za sve korisnike, sukladno načelu solidarnosti. Slična je situacija sa subvencioniranjem pružanja rezerviranih usluga prihodima od djelatnosti koje su otvorene za tržišno natjecanje. Problem nastaje ako se djelatnosti kod kojih postoji tržišno natjecanje subvencioniraju prebacivanjem njihovih troškova na rezervirane usluge te tada postoji opasnost od zlouporabe vladajućeg položaja. ${ }^{16}$

Klasičan primjer nedopuštenih unakrsnih subvencija odluka je Europske komisije u predmetu Deutsche Post. Ovdje je bila riječ o subvencioniranju gospodarske djelatnosti poslovnih

Ven, 'Voluntary Additional Health Insurance in the European Union: Free Market or Regulation?' (2017) 24 European Journal of Health Law 591, 606-607. Vidi i Sokol i Staničić (n 4) 812.

16 Vidi Obavijest Komisije o primjeni pravila o tržišnom natjecanju na poštanski sektor i o ocjeni određenih državnih mjera u vezi s poštanskim uslugama (1998) OJ C39/02. 
isporuka prihodima od monopola koji je Deutsche Post imao u djelatnosti univerzalne poštanske usluge. Zahvaljujući ovim prihodima, Deutsche Post je mogao predatornim cijenama dovesti u nepovoljan položaj vlastitu konkurenciju i na taj način zloupotrijebiti svoj vladajući položaj. Komisija je utvrdila povredu čl. 82. (današnjeg čl. 102.) Ugovora koji zabranjuje zlouporabu vladajućeg položaja te, osim novčane kazne, naložila Deutsche Postu otvaranje podružnice koja bi preuzela njegove tržišne aktivnosti. Pored toga, naloženo je da spomenuta podružnica mora na godišnjoj razini jasno prikazati sve transakcije s Deutsche Postom, kako bi se spriječilo daljnje unakrsno subvencioniranje prelijevanjem sredstava iz jednog subjekta u drugi. ${ }^{17}$

Tema unakrsnih subvencija u zdravstvenom sektoru pojavila se pred Sudom Europske unije u predmetu Ambulanz Glöckner. Riječ je bila o pitanju zdravstvenih usluga prijevoza u Njemačkoj. Pružanje ovih usluga bilo je uređeno na način da je hitni prijevoz bio odvojen od prijevoza (ostalih) pacijenata. Hitni prijevoz u Saveznoj pokrajini Porajnje-Falačka bio je povjeren isključivo dvjema medicinskim organizacijama (uključujući Crveni križ) koje su istovremeno pružala uslugu prijevoza pacijenata. Kada je privatni subjekt Ambulanz Glöckner tražio produljenje dozvole za pružanje usluge prijevoza pacijenata, organizacije su se usprotivile, s argumentom nedovoljne iskorištenosti vlastitih kapaciteta, što bi ih prisililo povećati cijenu usluga hitnog prijevoza ako bi Ambulanz Glöckner dobio produljene dozvole. Drugim riječima, ove organizacije koristile su isključivo pravo pružanja usluge hitnog prijevoza kako bi bilo održivo pružanje usluga od njihove strane na tržištu prijevoza pacijenata na kojem su se dotad natjecale s drugim (privatnim) subjektima. Sud je utvrdio da su pravila EU-a o tržišnom natjecanju primjenjiva, budući da su u pružanju predmetne usluge prethodno sudjelovali privatni subjekti, iz čega je proizlazilo da nije riječ o djelatnosti koju nužno obavljaju subjekti kojima su dana isključiva ili posebna prava. Sud je dalje zaključio da nacionalni pravni okvir koji omogućuje ovakav povlašten položaj pojedinim subjektima predstavlja ograničenje tržišnog natjecanja. Navedeno ograničenje ipak se može opravdati primjenom čl. 90. st. 2. Ugovora (danas čl. 106. st. 2.) kojim je propisano da poduzetnici kojima je povjereno obavljanje usluga od općeg gospodarskog interesa podliježu pravilima o tržišnom natjecanju, u onoj mjeri u kojoj primjena takvih pravila ne sprečava obavljanje posebnih zadaća koje su im povjerene. Potreba održavanja usluge od općeg gospodarskog interesa ovdje predstavlja opravdanje za odstupanje od pravila o tržišnom natjecanju EU-a. U konkretnom slučaju, Sud je utvrdio da potreba ekonomske održivosti pružanja usluge hitnog prijevoza pacijenata koji obavljanju subjekti s isključivim pravom, opravdava proširenje isključivih prava i na uslugu prijevoza ostalih pacijenata. ${ }^{18}$

Pored svega navedenog, svakako treba spomenuti i Direktivu Solventnost II. ${ }^{19}$ Navedena Direktiva donesena je s ciljem otklanjanja prepreka slobodi poslovnog nastana i slobodi pružanja usluga iz djelatnosti osiguranja na unutarnjem tržištu EU-a te, kao takva, ne spada u

17 Vidi 2001/354/EC: Commission Decision of 20 March 2001 relating to a proceeding under Article 82 of the EC Treaty (Case COMP/35.141 - Deutsche Post AG) (2001) OJ L125/27. Vidi o ovoj odluci i, primjerice, Giorgio Monti, EC Competition Law (CUP 2007) 478-484. Vidi također Andreas Bartosch, 'The Net Additional Costs of Discharging Public Service Obligations - The Commission's Deutsche Post Decision of 19 June 2002' (2002) 1 European State Aid Law Quarterly 183.

18 Vidi predmet C-475/99 Ambulanz Glöckner v Landkreis Südwestpfalz (2001) ECR I-8089. Vidi i Ana Poščić, 'Zabranjeni sporazumi u europskom pravu tržišnog natjecanja' (2011) 32 Zbornik Pravnog fakulteta Sveučilišta u Rijeci 319, 323. Vidi također Julia Lear, Elias Mossialos and Beatrix Karl, 'EU competition law and health policy' in Elias Mossialos and others (eds), Health Systems Governance in Europe The Role of European Union Law and Policy (CUP 2010).

19 Direktiva 2009/138/EC Europskog parlamenta i Vijeća od 25. studenoga 2009. o osnivanju i obavljanju djelatnosti osiguranja i reosiguranja (Solventnost II) (2009) OJ L335/1. 
područje primjene pravila o zaštiti tržišnog natjecanja i zabranjenim državnim potporama. Ipak, ona je relevantna jer uređuje uvjete obavljanja djelatnosti osiguranja te regulira navedeno tržište. Pri tome je važno napomenuti da je obvezno socijalno osiguranje, uključujući i obvezno zdravstveno osiguranje, čl. 3. izričito isključeno iz područja primjene Direktive. Također, čl. 206. Direktive propisano je da države članice mogu osiguranja, koja predstavljaju djelomičnu ili potpunu zamjenu za obvezno (socijalno) zdravstveno osiguranje, urediti posebnim zakonskim odredbama kako bi zaštitile opće dobro u toj vrsti osiguranja. Kao što je istaknuto u literaturi, situacije u kojima postoji obveza sklapanja ugovora sa svakom zainteresiranom osobom, premije su identične bez obzira na zdravstveno stanje osiguranika te postoji sustav ujednačavanja rizika, svakako su obuhvaćene ovom odredbom. ${ }^{20}$

Na kraju ovog dijela, može se zaključiti da su pravila Europske unije o zaštiti tržišnog natjecanja i zabranjenim državnim potporama relevantna u kontekstu dobrovoljnog dopunskog zdravstvenog osiguranja. Ona nisu primjenjiva na obvezno zdravstveno osiguranje u kojem postoji zakonski monopol javnog subjekta, no mogu biti primjenjiva na dobrovoljno dopunsko osiguranje ako u tom sektoru postoji stvarno tržišno natjecanje između poduzetnika. Država može intervenirati i u potonjem ako je potrebno omogućiti održivo pružanje usluge od općeg gospodarskog interesa te na taj način također isključiti primjenu pravila o zabranjenim državnim potporama ili opravdati odstupanje od pravila o tržišnom natjecanju. Pri tome je posebno važno da su pravila i način određivanja usluge od općeg gospodarskog interesa jasni i transparentni. Problematične su situacije u kojima jedan subjekt ima zakonski monopol u jednom sektoru na koji zbog toga tržišna pravila nisu primjenjiva (poput obveznog zdravstvenog osiguranja), a isti subjekt pruža usluge u drugom sektoru u kojem se tržišno natječe s drugim (privatnim) subjektima.

\section{NORMATIVNO UREĐENJE PODRUČJA DOBROVOLJNOG ZDRAVSTVENOG OSIGURANJA U REPUBLICI HRVATSKOJ}

Općenito govoreći, odgovor na pitanje zašto država intervenira u sustavu zdravstvenog osiguranja „treba tražiti u činjenici da je zdravlje pojedinca na višoj razini pitanje od općeg značenja te da se zbog nedovoljnog znanja pojedinca o potrebi zdravstvene zaštite javlja potreba državnog angažmana. Pojedinci, također, često nemaju spoznaju o potrebi i dobrim stranama zdravstvenog osiguranja te je država primorana zakonski ih prisiliti na osiguranje radi njihova osobnog dobra. “21 Načelno govoreći, obvezno zdravstveno osiguranje predstavlja upravo takav angažman države. Međutim, uz obvezno zdravstveno osiguranje, na kojem području kod nas postoji zakonski monopol državnog osiguratelja, postoji i više vrsta dobrovoljnih osiguranja. Kada, primjerice, pogledamo odredbe Zakona o osiguranju, ${ }^{22}$ vidjet ćemo da je izrijekom propisano da poslovi osiguranja prema tome Zakonu ne mogu biti obvezna zdravstvena osiguranja (čl. 7. st. 1.). Također, kao što je već napomenuto, u obveznom zdravstvenom osiguranju iznos

\footnotetext{
20 Vidi Tamara Hervey and Jean McHale, European Union Health Law: Themes and Implications (CUP 2015) 241-242.

21 Nikola Mijatović, 'Sustav socijalnog osiguranja i problemi njegova financiranja' ( 2006) 56 Zbornik Pravnog fakulteta u Zagrebu 1620. 
doprinosa i opseg usluga ne ovise o individualnom riziku. ${ }^{23}$ Ipak, postoji i područje dobrovoljnog zdravstvenog osiguranja, koje je također zakonodavno uredila država, a kojem ćemo se sada posvetiti.

U hrvatskom pravu, područje dobrovoljnog zdravstvenog osiguranja primarno je uređeno već spomenutim Zakonom o dobrovoljnom zdravstvenom osiguranju (ZDZO). Prema tome Zakonu, postoje tri vrste dobrovoljnog zdravstvenog osiguranja: dopunsko, dodatno i privatno zdravstveno osiguranje (članak 2.). Dopunsko i dodatno zdravstveno osiguranje ugovaraju se kao dugoročna osiguranja (najmanje u trajanju od jedne godine), a u skladu sa Zakonom o osiguranju ${ }^{24}$ predstavljaju neživotna ${ }^{25}$ osiguranja. U tom smislu, Zakon o osiguranju propisuje da zdravstveno osiguranje (ali dakako samo dobrovoljno) spada u neživotna osiguranja, a pokriva: fiksne novčane naknade, naknade u obliku odštete ili u naravi te kombinacije navedenih isplata (čl. 7. st. 2. t. 2.). Dakle, ovakvim osiguranjima se „pokrivaju troškovi liječenja osiguranika kada takve troškove sustav obveznog zdravstvenog osiguranja ne bi pokrivao ili se tim osiguranjem osiguraniku omogućuje pružanje zdravstvene usluge u većem opsegu i višem standardu (primjerice, specijalistički pregledi i dijagnostički postupci bez lista čekanja, lijekovi koje obvezno/državno zdravstveno osiguranje ne pokriva i sl.).“26

Dopunsko zdravstveno osiguranje jest osiguranje kojim se osigurava pokriće troškova zdravstvene zaštite iz obveznoga zdravstvenog osiguranja iz čl. 19. st. $3 .{ }^{27}$ i $4 .{ }^{28}$ i čl. 20. st.

23 Bitno drugačije je kod dobrovoljnog osiguranja, posebno kod onoga kojega pružaju privatni osiguratelji. Tako se u literaturi predlažu različiti modeli određivanja premije: „povezivanja premije s individualiziranim rizikom: iznos premije razlikuje se u skladu s preuzetim rizikom (veći rizik, veći iznos premije); ako su premije osiguranja jednake, rizik i opseg pokrića iz osiguranja mogu se usklađivati isključivanjem ili uključivanjem određenih benefita iz osiguranja; iznosi premije mogu se kombinirati u različitim paketima pogodnosti iz osiguranja; iznos bi se izračunao u skladu s rizikom, tj. odgovarajući paket i odgovarajuće pogodnosti." Vidi u: Nada Bodiroga-Vukobrat i Loris Belanić, 'Osigurani rizik u zdravstvenom osiguranju u svjetlu novih otkrića genetike' (2018) 39 Zbornik Pravnog fakulteta Sveučilišta u Rijeci 359.

Primjerice, kod nas je Zakonom o osiguranju propisano da se okolnost spola može uzeti kao faktor pri procjeni rizika kod zdravstvenog osiguranja (vidi čl. 8. st. 1.).

NN 30/2015, 112/2018, 63/2020

25 Vidi čl. 7. st. 2. Zakona o osiguranju (n 24) „Prava i obveze iz dobrovoljnog zdravstvenog osiguranja isključivo pripadaju osiguraniku i ne mogu se prenositi na druge osobe niti se mogu nasljeđivati, osim prava na novčana primanja, koja su osigurana putem dobrovoljnog zdravstvenog, a ostala su neisplaćena zbog smrti osiguranika." Vidi u: Ljubica Đukanović, 'Donesen je Zakon o dobrovoljnom zdravstzvenom osiguranju’ (2006) 9 Računovodstvo, revizija i financije 111.

26 Loris Belanić, 'Ugovor o dobrovoljnom zdravstvenom osiguranju' (2017) Pravo i porezi 25.

27 „Osigurane osobe obvezne su sudjelovati u troškovima zdravstvene zaštite u visini od $20 \%$ pune cijene zdravstvene zaštite, a koji iznos ne može biti manji od postotaka proračunske osnovice utvrđenih točkama 1. do 8. ovoga stavka za:

1. specijalističko-konzilijarnu zdravstvenu zaštitu, uključujući dnevnu bolnicu i kirurške zahvate u dnevnoj bolnici, osim ambulantne fizikalne medicine i rehabilitacije $-0,75 \%$ proračunske osnovice,

2. specijalističku dijagnostiku koja nije na razini primarne zdravstvene zaštite $-1,50 \%$ proračunske osnovice,

3. ortopedska i druga pomagala utvrđena osnovnom listom ortopedskih i drugih pomagala $-1,50 \%$ proračunske osnovice,

4. specijalističko-konzilijarnu zdravstvenu zaštitu u ambulantnoj fizikalnoj medicini i rehabilitaciji i za fizikalnu medicinu i rehabilitaciju u kući - 0,75\% proračunske osnovice po danu,

5. liječenje u drugim državama članicama i trećim državama sukladno propisima Europske unije, međunarodnom ugovoru, Direktivi 2011/24/EU, ovom Zakonu i općem aktu Zavoda, ako propisima Europske unije, odnosno međunarodnim ugovorom nije drukčije određeno,

6. troškove bolničke zdravstvene zaštite $-3,01 \%$ proračunske osnovice po danu,

7. dentalna pomagala utvrđena osnovnom listom dentalnih pomagala za odrasle osobe od 18 do 65 godina starosti - 30,07\% proračunske osnovice,

8. dentalna pomagala utvrđena osnovnom listom dentalnih pomagala za odrasle osobe starije od 65 godina $-15,03 \%$ proračunske osnovice."

28 „Osigurane osobe obvezne su sudjelovati u visini od 0,30\% proračunske osnovice za:

1. zdravstvenu zaštitu pruženu kod izabranog doktora primarne zdravstvene zaštite: obiteljske (opće) medicine, ginekologije i dentalne medicine, sukladno općem aktu Zavoda,

2. izdavanje lijeka po receptu." 
5. ${ }^{29}$ Zakona o obveznom zdravstvenom osiguranju (čl. 5. ZDZO-a). Dodatnim zdravstvenim osiguranjem osigurava se viši standard zdravstvene zaštite u odnosu na onaj iz obveznog zdravstvenog osiguranja te veći opseg prava u odnosu na prava iz obveznog osiguranja (čl. 6. ZDZO-a). Privatnim zdravstvenim osiguranjem osigurava se zdravstvena zaštita fizičkim osobama koje borave u Republici Hrvatskoj, a koje se nisu obvezne osigurati u skladu sa Zakonom o obveznom zdravstvenom osiguranju i Zakonu o obveznom zdravstvenom osiguranju i zdravstvenoj zaštiti stranaca u Republici Hrvatskoj. ${ }^{30}$

ZDZO propisuje da dobrovoljno zdravstveno osiguranje provodi društvo za osiguranje koje je dobilo dozvolu za obavljanje te vrste osiguranja od nadzornog tijela ${ }^{31} \mathrm{za}$ obavljanje poslova osiguranja u skladu sa Zakonom o osiguranju. ${ }^{32}$ Dodatno, prije započinjanja obavljanja poslova dobrovoljnog zdravstvenog osiguranja nužno je da društvo za osiguranje ishodi suglasnost ministra nadležnog za zdravstvo, u postupku uređenome Pravilnikom o postupku i načinu davanja suglasnosti za obavljanje poslova dobrovoljnog zdravstvenog osiguranja. ${ }^{33}$ Međutim, ZDZO propisuje jednu iznimku od navedenog načina obavljanja poslova dobrovoljnog zdravstvenog osiguranja jer propisuje da Hrvatski zavod za zdravstveno osiguranje (HZZO) ima pravo provoditi dopunsko zdravstveno osiguranje za pokriće troškova zdravstvene zaštite iz obveznoga zdravstvenog osiguranja iz čl. 19. st. 3. i 4. i čl. 20. st. 5. Zakona o obveznom zdravstvenom osiguranju. Iz ove zakonske odredbe proizlazi da je područje dobrovoljnog zdravstvenog osiguranja koje se sastoji, kako je već navedeno, od dopunskog, dodatnog i privatnog, razdvojeno na dva segmenta. U prvom segmentu djelatnost dobrovoljnog zdravstvenog osiguranja (privatno zdravstveno osiguranje) ne smije obavljati državni osiguratelj (HZZO), a u drugom segmentu djelatnost dopunskog i dodatnog zdravstvenog osiguranja kao posebno izdvojeni segment dobrovoljnog zdravstvenog osiguranja obavlja i državni osiguratelj HZZO, koji na području obveznog zdravstvenog osiguranja ima zakonski monopol. ${ }^{34}$ Naravno, sredstva koja uprihođuje bilo od dopunskog, bilo od dodatnog osiguranja HZZO mora voditi odvojeno od drugih sredstava koja uprihoduje s osnove obveznog zdravstvenog osiguranja. Dodatno, ova zakonska odredba uspostavlja HZZO kao pandan društvima za osiguranje koja provode dopunsko i dodatno zdravstveno osiguranje, ali bez posebnih dozvola koje izdaje HANFA, odnosno bez suglasnosti za rad koju izdaje ministar nadležan za zdravstvo jer je njegov položaj osiguratelja utvrđen zakonskom normom.

„Dopunska lista lijekova Zavoda, osim pune cijene lijeka, obvezno sadrži iznos sudjelovanja u cijeni lijeka koju osigurava osigurana osoba Zavoda neposredno ili putem dopunskog zdravstvenog osiguranja sukladno Zakonu o dobrovoljnom zdravstvenom osiguranju."

NN 80/2013, 15/2018

Hrvatske agencije za nadzor finacijskih usluga (HANFA), nap. a. izdaje odobrenje ako utvrdi da društvo ispunjava uvjete za obavljanje poslova osiguranja (vidi čl. 31. st. 2. Zakona o osiguranju). 


\subsection{DOPUNSKO ZDRAVSTVENO OSIGURANJE}

Dopunsko zdravstveno osiguranje ustanovljuje se posebnim ugovorom ${ }^{35}$ između osiguranika i privatnog osiguratelja, odnosno HZZO-a. Osiguratelj određuje premiju za dopunsko zdravstveno osiguranje s obzirom na opsege pokrića iz ugovora o osiguranju, dok HZZO cije$n u^{36}$ premije određuje svojim općim aktom s obzirom na opsege pokrića iz ugovora, prihodovnog cenzusa osiguranika i statusa osiguranika u obveznom zdravstvenom osiguranju (čl. 14. st. 1. i 2. ZDZO-a). Uvjete i način provođenja dopunskog zdravstvenog osiguranja utvrđuje ministar nadležan za zdravstvo koji je donio Pravilnik o uvjetima i načinu provođenja dopunskog zdravstvenog osiguranja. ${ }^{37} \mathrm{U}$ skladu s navedenim Pravilnikom, sklapanjem ugovora o dopunskom zdravstvenom osiguranju s osigurateljem, odnosno HZZO-om, osiguranik osigurava da pokriće troškova zdravstvene zaštite iz obveznog zdravstvenog osiguranja iz članka 16. stavka 3. i 4. i članka 17. stavka 5. Zakona o obveznom zdravstvenom osiguranju umjesto njega osigurava osiguratelj, odnosno HZZO. „Dopunsko zdravstveno osiguranje odnosi se na pokriće odnosno na participaciju (doplatu) troškova zdravstvene usluge (zdravstvene zaštite) iz obveznog zdravstvenog osiguranja u slučajevima kada HZZO takve troškove ne osigurava u potpunosti. ${ }^{\text {"38 }}$

\subsection{DODATNO ZDRAVSTVENO OSIGURANJE}

Dodatno zdravstveno osiguranje ustanovljuje se ugovorom o dodatnom zdravstvenom osiguranju između ugovaratelja osiguranja i osiguratelja, odnosno HZZO-a (čl. 17. ZDZO-a). Kod dodatnog zdravstvenog osiguranja i privatni osiguratelji i HZZO određuju premiju s obzirom na opseg pokrića iz ugovora o dodatnom zdravstvenom osiguranju te rizik kojem je osiguranik izložen, uzimajući u obzir dob, spol, bonus i malus, tablice smrtnosti i tablice bolesti te trajanje sklopljenog ugovora o osiguranju. Postoji obveza sklapanja ugovora o osiguranju sa svim osiguranicima HZZO-a (nosiocima obveznog zdravstvenog osiguranja) te obveza osiguranja jednakih prava i obveza iz dodatnoga zdravstvenog osiguranja po pojedinom programu osiguratelja (čl. 20. ZDZO-a). „Kod dodatnog zdravstvenog osiguranja pokriće se odnosi na viši standard zdravstvene zaštite i veći opseg prava u odnosu na obvezno zdravstveno osiguranje.“" ${ }^{\text {“9 }}$ Međutim, zasad HZZO ne pruža uslugu dodatnog zdravstvenog osiguranja.

35 „Glede materijalnopravnih odredbi kojima se uređuje ugovor o dobrovoljnom zdravstvenom osiguranju primjenjuju se opće odredbe Zakona o obveznim odnosima, NN 35/2005, 41/2008, 125/2011, 78/2015, 29/2018 o ugovoru o osiguranju. Drugim riječima, u Hrvatskoj je prisutan nedostatak zakonskog uređenja materijalnopravnih odredbi ugovora o dobrovoljnom zdravstvenom osiguranju, zbog čega su najznačajniji materijalnopravni izvori ugovora o dobrovoljnom zdravstvenom osiguranju uvjeti pojedinih osiguratelja." Belanić (n 26) 25.

Treba naglasiti da se, u skladu s čl. 14.a ZDZO-a sredstva za određene kategorije osiguranika sredstva za premiju dopunskog zdravstvenog osiguranja koje provodi HZZO osiguravaju u državnom proračunu. Postupak utvrđivaja prava na plaćanje premije dopunskog zdravstvenog osiguranja iz državnog proračuna propisan je Pravilnik o postupku, uvjetima i načinu utvrđivanja prava na plaćanje premije dopunskog zdravstvenog osiguranja iz državnog proračuna, NN 156/2008, 88/2010, 31/2016, 116/2017, $106 / 2018,65 / 2020$. 


\subsection{PRIVATNO ZDRAVSTVENO OSIGURANJE}

Privatno zdravstveno osiguranje ustanovljuje se ugovorom o privatnom zdravstvenom osiguranju između ugovaratelja osiguranja i osiguratelja (čl. 26. ZDZO-a). Osiguratelj određuje premiju za privatno zdravstveno osiguranje s obzirom na opseg pokrića iz ugovora o privatnom zdravstvenom osiguranju te rizik kojem je osiguranik izložen, uzimajući u obzir dob, spol, bonus i malus, tablice smrtnosti i tablice bolesti te trajanje sklopljenog ugovora o osiguranju, uz obvezu osiguranja jednakih prava i obveza za osiguranike iz privatnoga zdravstvenog osiguranja po pojedinom programu osiguratelja (čl. 29. ZDZO-a). Dozvolu za obavljanje privatnog zdravstvenog osiguranja daje nadzorno tijelo za obavljanje poslova osiguranja - HANFA. ${ }^{40}$

\section{USKLAĐENOST NORMATIVNOG OKVIRA DOBROVOLJNOG ZDRAVSTVENOG OSIGURANJA S PRAVOM EUROPSKE UNIJE}

O pitanju usklađenosti normativnog okvira koji uređuje dobrovoljno zdravstveno osiguranje u Republici Hrvatskoj s pravom Europske unije već se, ali nažalost malo, pisalo u našoj pravnoj literaturi. ${ }^{41}$ Temeljna kritika odnosila se na činjenicu da odredbe ZDZO-a „omogućuju da HZZO provodi dopunsko i dodatno zdravstveno osiguranje bez pridržavanja odredbi Zakona o osiguranju (npr. o formiranju rezervi) i bez nadzora regulatornog tijela Hrvatske agencije za nadzor financijskih usluga (HANFA) što ima za posljedicu da spomenute odredbe nisu u skladu s propisima EU-a o djelatnosti osiguranja. Ujedno se na taj način HZZO (kao državni socijalni osiguratelj) stavlja u povlašten položaj u odnosu na društva za osiguranje “. 42 Odnosno, navodilo se da HZZO, koji ne posluje prema načelima Zakona o osiguranju, predstavlja nepoštenu konkurenciju prema privatnim osigurateljima. ${ }^{43}$ Međutim, treba naglasiti da jest točno da europska pravila propisuju da se neživotna osiguranja moraju obavljati prema pravilima za osiguranje i pod nadzorom regulatora, ali točno je i da predviđaju iznimke, kao što je već navedeno, ${ }^{44}$ za zdravstveno osiguranje koje je dijelom socijalnog osiguranja. Dakako, treba razmotriti i pitanje je li riječ možda u slučaju dopunskog osiguranja koje pruža HZZO o nedopuštenim državnim potporama prema opisanim pravilima prava EU-a. Kako je već navedeno, sustav dobrovoljnog zdravstvenog osiguranja neće biti obuhvaćen pravilima o državnim potporama ako on predstavlja uslugu od općeg gospodarskog interesa koju pruža javni subjekt koji ima obvezu sklapanja u ugovora sa svakom zainteresiranom osobom, bez obzira na njezino zdravstveno stanje, dob i spol, s premijama koje su identične bez obzira na zdravstveno stanje osiguranika. U potonjem slučaju država može intervenirati kroz sustav ujednačavanja rizika koji je proporcionalan svojoj svrsi, s jasno i transparentno određenim kriterijima za

\footnotetext{
$40 \quad$ Đukanović (n 25) 112.

41 Vidi Nensi Botica Jukić, 'Usklađenost Zakona o dobrovoljnom zdravstvenom osiguranju s pravnom stečevinom Europske unije' (2015) 56 Osiguranje, 30-33 i Belanić (n 26) 25.

42 Vidi Botica Jukić (n 41) 33.

43 Belanić (n 26) 25.

44 Vidi čl. 3. Direktive 2009/138 (n 18) i čl. 2. t. 1. d. 73/239/EEZ: Prve direktive Vijeća od 24. srpnja 1973. o usklađivanju zakona i drugih propisa koji u odnosu na osnivanje i obavljanje poslova izravnog osiguranja osim životnog osiguranja (1973) OJ L228/3.
} 
transfer sredstava onim subjektima koji pružaju ovakvu uslugu. U slučaju HZZO-a i njegova pružanja usluge dopunskog zdravstvenog osiguranja nedvojbeno je da HZZO ima zakonsku obvezu sklopiti ugovor o dopunskom osiguranju sa svim (svojim) osiguranicima obveznog zdravstvenog osiguranja koji to zatraže, a u skladu s čl. 14. st. 3. al. 1. ZDZO-a. Nedvojbeno je i da državni proračun isplaćuje premiju osiguranja za niz kategorija korisnika u korist HZZO-a. Kada pogledamo sustav premija dopunskog osiguranja koje provodi $\mathrm{HZZO}$, vidjet ćemo da je na temelju Odluke o cijeni police dopunskog zdravstvenog osiguranja ${ }^{45}$ cijena police kojom HZZO pokriva pokriće sudjelovanja u troškovima zdravstvene zaštite određena u jednakom iznosu od 840,00 kuna na godinu, donosno 70,00 kuna na mjesec za sve osiguranike. Prema tome, cijena premije identična je za svakog osiguranika, bez obzira na njegovo zdravstveno stanje, dob i spol. U tom smislu, zadovoljen je dio uvjeta da sustav dopunskog zdravstvenog osiguranja ne bude obuhvaćen pravilima o državnim potporama.

Međutim, treba vidjeti je li riječ u primjeru HZZO-a o situaciji u kojoj u nekoj djelatnosti nema tržišnog natjecanja budući da određeni subjekt ima zakonski monopol na obavljanje te djelatnosti, a koristi takav položaj da u nekoj drugoj djelatnosti ostvari i zlouporabi vladajući položaj, što je zabranjeno čl. 102. Ugovora o funkcioniranju Europske unije. Naime, već je objašnjeno da HZZO ima zakonski monopol na području obveznog zdravstvenog osiguranja te je nužno provjeriti koristi li HZZO taj zakonski monopol kako bi ostvario i zlouporabio vladajući položaj na području dopunskog zdravstvenog osiguranja. Treba naglasiti i da osiguranik u sustavu dopunskog zdravstvenog osiguranja može biti samo osoba koja ima utvrđen status osigurane osobe u obveznom zdravstvenom osiguranju, prema čl. 13. st. 2. ZDZO-a. S druge strane, važno je napomenuti da HZZO sredstva uprihođena od dopunskog osiguranja vodi kroz odvojeno financijsko poslovanje, kao što je propisano ZDZO-om i uređeno Odlukom o načinu osiguravanja i raspolaganja sredstvima dopunskog zdravstvenog osiguranja. ${ }^{46}$ Osim toga, navedena Odluka propisuje da se sredstva za provođenje dopunskog zdravstvenog osiguranja u HZZO-u osiguravaju iz prihoda dopunskog zdravstvenog osiguranja (čl. 2.). Ipak, nedvojbeno je da HZZO koristi infrastrukturu koja je izgrađena u svrhu pružanja obveznog zdravstvenog osiguranja jer se ugovor o dopunskom zdravstvenom osiguranju može sklopiti u svim regionalnim uredima, područnim službama HZZO-a i njihovim ispostavama. ${ }^{47} \mathrm{U}$ tom kontekstu može se govoriti o iskorištavanju povoljnijeg položaja na tržištu u smislu jednostavnije i sveobuhvatnije dostupnosti svakom potencijalnom osiguraniku koja dodatno proizlazi iz činjenice da se regionalne službe, područne službe i ispostave kao i troškovi njihovih zaposlenika primarno financiraju iz prihoda HZZO-a kao državnog monopolista, pa njegov položaj u ovom kontekstu nije usporediv, primjerice s činjenicom da i privatni osiguratelji imaju „mrežu“ poslovnica u RH. Osim toga, ta mreža u većini slučajeva nije usporediva s razgranatom mrežom HZZO-a.

Osim toga, treba posebno naglasiti činjenicu da je HZZO jedini pružatelj dopunskog osiguranja kod kojega premiju za niz kategorija osiguranika izravno plaća državni proračun. U

\footnotetext{
45 NN 118/2013.

46 NN 91/2013.

47 Vidi čl. 9. st. 1. Pravila uspostavljanja i provođenja dopunskog zdravstvenog osiguranja, NN 91/2013, 136/2013, 21/2014, $135 / 2014,144 / 2014,42 / 2018$.
} 
smislu čl. 14.a ZDZO-a, sredstva za premiju dopunskog zdravstvenog osiguranja koje provodi HZZO osigurava se u državnom proračunu za sljedeće kategorije $e^{48}$ osiguranika:

1. osigurane osobe s invaliditetom koje imaju $100 \%$ oštećenja organizma, odnosno tjelesnog oštećenja prema posebnim propisima, osobe kod kojih je utvrđeno više vrsta oštećenja te osobe s tjelesnim ili mentalnim oštećenjem ili psihičkom bolešću zbog kojih ne mogu samostalno izvoditi aktivnosti primjerene životnoj dobi sukladno propisima o socijalnoj skrbi,

2. osigurane osobe darivatelje dijelova ljudskog tijela u svrhu liječenja,

3. osigurane osobe dobrovoljne davatelje krvi s više od 35 davanja (muškarci), odnosno $s$ više od 25 davanja (žene),

4. osigurane osobe redovite učenike i studente starije od 18 godina,

5. osigurane osobe čiji prihod po članu obitelji u prethodnoj kalendarskoj godini ne prelazi iznos utvrđen čl. 14.b ZDZO-a.

Posebno treba naglasiti da je kategorija 5. (osigurane osobe čiji prihod po članu obitelji u prethodnoj kalendarskoj godini ne prelazi iznos utvrđen člankom 14.b ZDZO-a) relativno široko postavljena jer je iznos koji je određen čl. 14.b. st. 1. ZDZO-a 1.563,23 kune po članu obitelji (za samce je iznos postavljen na 2.000,00 kuna). U tom kontekstu, iluzorno je očekivati da osobe koje imaju takva primanja mogu sklopiti ugovore o dobrovoljnom (dopunskom) osiguranju s privatnim osigurateljima. S druge strane, država je preuzela obvezu plaćati premiju osiguranja za sve takve osobe, ali isključivo jednom pružatelju usluge dopunskog zdravstvenog osiguranja - HZZO-u. ${ }^{49}$ Broj osiguranih osoba koji ostvaruju pravo na plaćanje premije dopunskoga zdravstvenog osiguranja iz sredstava državnog proračuna Republike Hrvatske u 2019. godini bio je 666.777 osiguranika po sljedećim osnovama: ${ }^{50}$

\begin{tabular}{|l|r|}
\hline $\begin{array}{l}\text { osigurane osobe - dobrovoljni davatelji krvi s više od 35 davanja (muškarci), odnosno s } \\
\text { više od } 25 \text { davanja (žene) }\end{array}$ & 46.301 \\
\hline osigurane osobe - redoviti učenici i studenti stariji od 18 godina & 170.940 \\
\hline prihodovni cenzus - osigurane osobe Zavoda (1.516,32 kn) & 254.040 \\
\hline osigurane osobe darivatelji organa & 482 \\
\hline $\begin{array}{l}\text { osigurane osobe - 100\% invalidi ako imaju privremeno rješenje o utvrđenom invaliditetu } \\
\text { na određeno vrijeme }\end{array}$ & 15 \\
\hline $\begin{array}{l}\text { osigurane osobe - 100\% tjelesno oštećenje ako imaju privremeno rješenje o utvrđenom } \\
\text { tjelesnom oštećenju na određeno vrijeme }\end{array}$ & 28 \\
\hline prihodovni cenzus - osiguranik samac (1.939,39 kn) & 124.462 \\
\hline $\begin{array}{l}\text { osigurane osobe s više vrsta oštećenja te osobe s tjelesnim ili mentalnim oštećenjem ili } \\
\text { psihičkom bolešću zbog kojih ne mogu samostalno izvoditi aktivnosti primjerene životnoj } \\
\text { dobi ako imaju privremeno rješenje o utvrđenom tjelesnom ili mentalnom oštećenju ili } \\
\text { psihičkoj bolesti na određeno vrijeme }\end{array}$ & 3.147 \\
\hline osigurane osobe - 100\% invalidi ako imaju trajno rješenje o utvrđenom invaliditetu & 1.351 \\
\hline
\end{tabular}

48 Kategorije su proširene posebnim zakonima, detaljan popis vidi u Ljubica Đukanović, 'Dopunsko zdravstveno osiguranje' (2010) 5 Financije i porezi 139, 140-141.

49 Treba naglasiti da je HZZO od 1. siječnja 2015. godine izašao iz sustava državne riznice.

50 Izvor: Vlada Republike Hrvatske 'Konačni prijedlog Zakona o izmjenama i dopuni Zakona o dobrovoljnom zdravstvenom osiguranju’ (Hrvatski sabor PZ br. 934) <https://www.sabor.hr/sites/default/files/uploadssabor/2020-04-23/180002/PZ_934. pdf> pristupljeno 11. lipnja 2020. 
osigurane osobe - $100 \%$ tjelesno oštećenje ako imaju trajno rješenje o utvrđenom tjelesnom oštećenju

osigurane osobe $s$ više vrsta oštećenja te osobe s tjelesnim ili mentalnim oštećenjem ili psihičkom bolešću zbog kojih ne mogu samostalno izvoditi aktivnosti primjerene životnoj dobi ako imaju trajno rješenje o utvrđenom tjelesnom ili mentalnom oštećenju sukladno propisima o socijalnoj skrbi žrtve seksualnog nasilja u Domovinskom ratu - Ministarstvo hrvatskih branitelja

Navedeno znači da privatni osiguratelji ne mogu računati na najmanje 666.777 potencijalnih osiguranika, a za koje sigurne, ${ }^{51}$ zakonski propisane prihode ostvaruje državni pružatelj dopunskog zdravstvenog osiguranja.

Kao dodatni argumenti povlaštenog položaja HZZO-a na području dopunskog zdravstvenog osiguranja isticalo se da HZZO dopunsko osiguranje ne provodi prema odredbama Zakona o osiguranju (način definiranja uvjeta osiguranja, marketing i sl.), da poslovanje nije pod kontrolom regulatora već kontrolu provodi nadležno ministarstvo (dok kontrolu svih ostalih osiguratelja provodi HANFA kao neovisni regulator), da se u poslovanju koristi infrastruktura obveznog zdravstvenog osiguranja (informatički sustav, sklapanje ugovora sa zdravstvenim ustanovama, prodaja osiguranja i sl.) i da nema obveze formiranja pričuva. ${ }^{52,53}$ Posebno treba istaknuti da HZZO koristi usluge Centralnog zdravstvenog informacijskog sustava (CEZIH) na koji su spojeni svi provoditelji zdravstvene zaštite u Hrvatskoj, ${ }^{54}$ čime je omogućeno da iskaznica dopunskog zdravstvenog sustava koju izdaje HZZO bude sredstvo bezgotovinskog plaćanja sudjelovanja odnosno participacije. ${ }^{55}$ Ujedno, HZZO je operator CEZIH-a, pa je mogao ograničavati pristup drugim osiguravajućim kućama koje su morale ući u pregovore s HZZOom i sklopiti s njim ugovor o načinu pristupa sustavu i visini naknade za održavanje i korištenje. ${ }^{56}$ Kao kritika isticala se i činjenica „da HZZO, kao regulator i provoditelj ovog osiguranja, može utjecati na iznose sudjelovanja u zdravstvenoj zaštiti i mijenjati lijekove na dopunskoj listi (što) predstavlja monopolni utjecaj. To komercijalne osiguratelje stavlja u nepovoljniji po-

51 Unatoč ovome, pokazalo se da je ukupni financijski efekt dopunskog zdravstvenog osiguranja za HZZO (barem u razdobljlu do 2013. godine) bio negativan. Kako navode Broz i Švaljek „čini se da je ulazak velikog dijela stanovništva u sustav dopunskog osiguranja uvećao problem nepovoljnog odabira i moralnog hazarda. To se vidi iz podataka za 2010. godinu, gdje je saldo dopunskog osiguranja negativan, odnosno manjak iznosi 260,8 milijuna kuna. Naime, pretpostavka je da će osobe slabijeg ili rizičnijeg zdravstvenog stanja biti sklonije uplatiti dopunsko zdravstveno osiguranje, budući da očekuju da će više koristiti zdravstvene usluge. Osim toga, cijena dopunskog zdravstvenog osiguranja ne ovisi o zdravstvenom stanju, već o visini dohotka, što znači da je nekim osobama slabijeg ili rizičnijeg zdravstvenog stanja cijena police niža nego što bi trebala biti, odnosno da liječenje tih osiguranika subvencioniraju osiguranici boljeg ili manje rizičnog zdravlja. Zbog toga dolazi do većih rashoda od prihoda po toj osnovi te se dopunsko zdravstveno osiguranje našlo u gubicima. Smanjenje moralnog hazarda i nepovoljnog odabira može se postići upravo sudjelovanjem u troškovima liječenja (plaćanjem "iz džepa" ili povećanjem cijene dopunskog osiguranja)." Vidi u Tanja Broz i Sandra Švaljek, 'Financiranje zdravstva u Hrvatskoj: od reforme do reforme' u Maja Vehovec (ed), O zdravstvu iz ekonomske perspektive (Ekonomski institut 2014) 60. zdravstvenog osiguranja (vidi čl. 6. st. 2. u vezi s čl. 8.), nap. a.

54 Mario Bagat, 'Tržište dopunskog zdravstvenog osiguranja - očekivanja u 2014. godini' (2013) 54 Osiguranje 57. 
ložaj zbog rizika od nekontroliranog povećanja participacije, a samim time i obveze prema osiguranicima što direktno utječe na njihovo poslovanje. “57

Zaključno, HZZO pruža uslugu dopunskog zdravstvenog osiguranja na nedvojbeno postojećem tržištu usluga dopunskog zdravstvenog osiguranja. Nedvojbeno je da uslugu dopunskog zdravstvenog osiguranja pruža na sljedeći način:

a) dužan je sklopiti policu sa svim osiguranicima s jednakom premijom i osigurati im jednaki paket usluga bez obzira na njihovu dob, spol i zdravstveno stanje;

b) ne pruža uslugu prema odredbama Zakona o osiguranju i nije pod nadzorom neovisnog regulatora (HANFA-e) nego nadležnog ministarstva;

c) jedini uživa pogodnost da za određene kategorije (više od 600.000) osiguranika premiju isplaćuje državni proračun, što bi se moglo smatrati državnom potporom;

d) koristi infrastrukturu HZZO-a kao državnog osiguratelja obveznog zdravstvenog osiguranja koji ima zakonski monopol (sklapanje ugovora u ispostavama);

e) ne plaća, za razliku od ostalih osiguratelja, pristup CEZIH-u jer je riječ o sustavu kojega je sam operater, u funkciji pružatelja obveznog zdravstvenog osiguranja.

Iz svega navedenoga morao bi se iskristalizirati odgovor na pitanje koje se pojavilo glede pružanja usluge dopunskog zdravstvenog osiguranja od strane HZZO-a - je li riječ o dijelu socijalnog zdravstvenog osiguranja? Ako jest, nisu primjenjiva pravila o državnim potporama iz prava EU-a, kao što je i na djelu primjena iznimke iz Direktive Solventnost II. Odnosno, u tom slučaju nije sporno da je hrvatski pravni sustav usklađen s pravom EU-a. S druge strane, ako je odgovor na postavljeno pitanje negativan, onda bi se moglo smatrati da naš sustav nije u skladu s pravilima o državnim potporama, kao i da je pružanje dopunskog zdravstvenog osiguranja od strane HZZO-a protivno Direktivi Solventnost II.

\section{STVARANJE NOVOG SUBJEKTA KAO RJEŠENJE?}

Dosadašnja analiza ukazala je na nekoliko važnih činjenica vezanih uz zdravstveno osiguranje i ulogu HZZO-a u kontekstu europskih pravila o tržišnom natjecanju i državnim potporama. Prvo, navedena pravila nisu primjenjiva na obvezno zdravstveno osiguranje, budući da ono ne predstavlja gospodarsku aktivnost u smislu prava EU-a. Drugo, dopunsko zdravstveno osiguranje, kakvo postoji u Republici Hrvatskoj, predstavlja gospodarsku aktivnost. Utemeljenje je ove tvrdnje u činjenici da u sferi dopunskog zdravstvenog osiguranja u Hrvatskoj nedvojbeno postoji stvarno tržišno natjecanje između poduzetnika, s HANFA-om kao regulatorom koji i nadzire društva za osiguranje na tržištu. S druge strane, budući da stvarno tržišno natjecanje postoji, može se ustvrditi da posebna pravila koja se primjenjuju na HZZO dovode do njegova povlaštenog položaja u odnosu na društva za osiguranje na koja se ta pravila ne primjenjuju. Navedeni povlašteni položaj dodatno je ojačan činjenicom da HZZO kao zakonski monopolist obveznog zdravstvenog osiguranja koristi svoju infrastrukturu u sferi dopunskog zdravstvenog osiguranja, što mu omogućuje smanjenje troškova u odnosu na društva za osiguranje koja nemaju takvu povlasticu i kao takvo predstavlja unakrsnu subvenciju.

57 Mario Puljiz, 'Dobrovoljno zdravstveno osiguranje' u Maja Vehovec (ed), O zdravstvu iz ekonomske perspektive (Ekonomski institut 2014) 116. 
Opisana povlaštena uloga HZZO-a na tržištu dopunskog zdravstvenog osiguranja mogla bi se opravdati potrebom održavanja usluge od općeg gospodarskog interesa. Glavni argument u korist ove teze jest da je HZZO dužan sklopiti policu sa svim osiguranicima s jednakom premijom i osigurati im jednaki paket usluga bez obzira na njihovu dob, spol i zdravstveno stanje, za razliku od društava za osiguranje. Ipak, važno je naglasiti da posebna pravila koja se u tom smislu odnose na HZZO moraju biti proporcionalna svojoj svrsi (zaštiti općeg interesa), s jasno i transparentno određenim kriterijima koji se pri tome primjenjuju. U kontekstu HZZO-a, s isprepletenim djelatnostima obveznog i dopunskog zdravstvenog osiguranja, propisanim djelomičnim proračunskim financiranjem te korištenjem zakonskog monopola (uključujući pripadajuću infrastrukturu) u jednom sektoru za poboljšanje vlastita položaja u drugom sektoru, teško da se može reći da je navedeni uvjet zadovoljen.

Kako riješiti opisani problem? Sudska praksa, poput presude u predmetu BUPA, upućuje na to da je najbolji i svakako najtransparentniji način osnivanje posebnog pravnog subjekta (javne ustanove) od strane države koji bi se bavio djelatnošću dopunskog zdravstvenog osiguranja. Položaj i ovlasti navedenog subjekta bili bi uređeni posebnim zakonom kojim bi mu bila povjerena obveza pružanja jasno definirane javne usluge (slično kao sada ZDZO-om) u smislu obveze sklapanja police sa svim osiguranicima s jednakom premijom i zajamčenim jednakim paketom usluga bez obzira na njihovu dob, spol i zdravstveno stanje. Ono što bi bila novina u odnosu na sadašnji sustav jest sustav ujednačavanja rizika. Prema ovom sustavu, privatna društva za osiguranje osnovana s ciljem ostvarivanja dobiti morala bi, sukladno jasno i objektivno propisanim kriterijima, transferirati sredstva novom subjektu koji bi, za razliku od njih, morao sklapati ugovore s osiguranicima svih profila, uključujući i one s nepovoljnijim profilom rizika od tržišnog. Na ovaj način transfer sredstava bio bi sveden na najmanju mjeru potrebnu da pružatelj usluge od općeg gospodarskog interesa može doista i ispuniti obvezu pružanja navedene usluge. ${ }^{58}$

U predloženom bi okviru uvjeti iz predmeta Altmark bili zadovoljeni, a sama činjenica da je riječ o posebnom pravnom subjektu odvojenom od HZZO-a otklonila bi problem korištenja infrastrukture iz sektora obveznog zdravstvenog osiguranja za osiguranje povlaštenog položaja na tržištu dopunskog zdravstvenog osiguranja. Država bi i dalje intervenirala na tržištu dopunskog zdravstvenog osiguranja kako bi omogućila pružanje usluge od općeg gospodarskog interesa onima kojima je ona potrebna. Za razliku od trenutačnog stanja, navedena intervencija zadovoljila bi test proporcionalnosti prema kojem ona ne smije ići dalje od onoga što je nužno kako bi se postigao cilj zaštite općeg interesa, s jasno i transparentno propisanim kriterijima za transfer sredstava onim subjektima koji pružaju ovakvu uslugu. Na ovaj način, pomirila bi se potreba očuvanja usluge od općeg interesa, odnosno dostupnosti dopunskog zdravstvenog osiguranja svim osobama uključujući one sa slabijim profilom rizika (starije osobe, kronični bolesnici i slično), s tržišnim natjecanjem u Republici Hrvatskoj kao jednoj od država članica Europske unije.

58 Sličan sustav postoji, primjerice, u Sloveniji. Vidi čl. 62.-62. Zakon o zdravstvenem varstvu i zdravstvenem zavarovanju (UL 9/1992, 72/2006, 114/2006, 91/2007, 135/2014, 76/2008, 62/2010, 87/2011, 40/2012. 21/2013, 91/2013, 99/2013, 111/2013, 95/2014, 47/2015, 61/2017, 64/2017, 36/2019) (SI). 


\section{ZAKLJUČAK}

Pravila Europske unije o tržišnom natjecanju i zabranjenim državnim potporama primjenjiva su na poduzetnike koji obavljaju gospodarsku aktivnost bez obzira na način njihova financiranja, odnosno jesu li u državnom ili privatnom vlasništvu. Više je kriterija koje Sud Europske unije uzima u obzir pri određivanju je li riječ u nekoj situaciji o gospodarskoj aktivnosti ili ne, a ključno je pitanje je li država svojim aktima isključila određene djelatnosti iz sfere tržišnog natjecanja. Ondje gdje postoji natjecanje i subjekti snose poslovni rizik tog natjecanja, može se govoriti o gospodarskoj djelatnosti na koju su primjenjiva tržišna pravila Europske unije. Pravila o državnim potporama također nisu primjenjiva ako je u pojedinom slučaju riječ o usluzi od općeg gospodarskog interesa, pri čemu su zadovoljeni uvjeti koje je definirao Sud Europske unije u predmetu Altmark. Ovdje je ključno da posebna pravila koja se primjenjuju na određeni subjekt ne idu dalje od onog što je nužno za zaštitu općeg interesa u konkretnoj situaciji, odnosno da ne daju privilegirani položaj subjektu koji pruža navedenu uslugu na način kojim bi se kršilo načelo proporcionalnosti u pravu Europske unije. Kad tržišna pravila Unije jesu primjenjiva u konkretnom slučaju, posebno je problematično ako određeni subjekt ima zakonski monopol u jednom sektoru na koji zbog toga tržišna pravila nisu primjenjiva, a isti subjekt pruža usluge u drugom sektoru u kojem se tržišno natječe s drugim subjektima i koristi takvu poziciju da našteti vlastitoj konkurenciji na potonjem tržištu.

U konteksu zdravstvenog osiguranja u Republici Hrvatskoj, pravila o tržišnom natjecanju i državnim potporama svakako nisu primjenjiva na obvezno zdravstveno osiguranje, budući da ono ne predstavlja gospodarsku aktivnost u smislu prava Unije. S druge strane, dopunsko zdravstveno osiguranje, kakvo postoji u Republici Hrvatskoj, predstavlja gospodarsku aktivnost, budući da u ovom području u Hrvatskoj nedvojbeno postoji stvarno tržišno natjecanje između poduzetnika, s HANFA-om kao regulatorom koji i nadzire društva za osiguranje na tržištu. U opisanoj situaciji postojanja natjecanja na tržištu dopunskog zdravstvenog osiguranja, može se ustvrditi da posebna pravila koja se primjenjuju na HZZO dovode do njegova povlaštenog položaja u odnosu na društva za osiguranje na koja se ta pravila ne primjenjuju. Navedeni povlašteni položaj dodatno je ojačan činjenicom da HZZO kao zakonski monopolist obveznog zdravstvenog osiguranja koristi svoju infrastrukturu u sferi dopunskog zdravstvenog osiguranja, što mu omogućuje smanjenje troškova u odnosu na društva za osiguranje koja nemaju takvu povlasticu.

Rješenje za navedenu situaciju može biti osnivanje posebnog subjekta od strane države koji bi obavljao djelatnost dopunskog zdravstvenog osiguranja. Ovakav subjekt morao bi sklapati police sa svim osiguranicima s jednakom premijom i zajamčenim jednakim paketom usluga bez obzira na njihovu dob, spol i zdravstveno stanje. Kako bi se spriječilo da privatni konkurenti, preuzimanjem isključivo osiguranika s povoljnijim profilom rizika, ugroze funkcioniranje usluge od općeg interesa, oni bi morali, prema jasno i objektivno određenim kriterijima, transferirati sredstva javnom subjektu koji bi, za razliku od njih, morao sklapati ugovore s osiguranicima svih profila, uključujući i one s nepovoljnijim profilom rizika od tržišnog, poput starijih osoba i kroničnih bolesnika. Na ovaj način, pomirila bi se potreba očuvanja usluge od općeg interesa, odnosno dostupnosti dopunskog zdravstvenog osiguranja svim osobama uključujući one sa slabijim profilom rizika, s natjecanjem na unutarnjem tržištu Europske unije. 


\section{BIBLIOGRAFIJA}

1. Bagat M, 'Tržište dopunskog zdravstvenog osiguranja: očekivanja u 2014. godini' (2013) 54(12) Osiguranje 56

2. Bartosch A, "The „Net Additional Costs“ of Discharging Public Service Obligations: The Commission's Deutsche Post Decision of 19 June 2002' (2002) 1(2) European State Aid Law Quarterly 183

3. Belanić L, 'Ugovor o dobrovoljnom zdravstvenom osiguranju' (2017) 26(9) Pravo i porezi 25

4. Bodiroga-Vukobrat N i Belanić L, 'Osigurani rizik u zdravstvenom osiguranju u svjetlu novih otkrića genetike' (2018) 39(1) Zbornik Pravnog fakulteta Sveučilišta u Rijeci 353

5. Botica Jukić N, 'Usklađenost Zakona o dobrovoljnom zdravstvenom osiguranju s pravnom stečevinom Europske unije' (2015) 56(1) Osiguranje 30

6. Broz T i Švaljek S, 'Financiranje zdravstva u Hrvatskoj: od reforme do reforme’ u Maja Vehovec (ed), O zdravstvu iz ekonomske perspektive (Ekonomski institut 2014)

7. Calcoen P and van de Ven WPMM, 'Voluntary Additional Health Insurance in the European Union: Free Market or Regulation?' (2017) 24 European Journal of Health Law $591<$ https://doi. org/10.1163/15718093-12460339> pristupljeno 16. srpnja 2021.

8. Cerovac M, 'Pojam poduzetnika u pravu tržišnog natjecanja' (2005) 5(10) Hrvatska pravna revija 61

9. Department of Health and Children (Ireland), Report of the Expert Group on Resource Allocation and Financing in the Health Sector (Government Publications 2010) <www.esri.ie/system/files/media/ file-uploads/2015-07/BKMNEXT171.pdf> pristupljeno 16. srpnja 2021.

10. Đukanović Lj, 'Donesen je Zakon o dobrovoljnom zdravstvenom osiguranju' (2006) 16(9) Računovodstvo, revizija i financije 111

11. Đukanović Lj, 'Dopunsko zdravstveno osiguranje' (2010) 17(5) Financije i porezi 139

12. Hatzopoulos VG, 'Killing National Health and Insurance Systems but Healing Patients? The European Market for Health Care Services after the Judgements of the ECJ in Vanbraekel and Peerbooms' (2002) 39 Common Market Law Review 683

13. Hervey $\mathrm{T}$ and McHale J, European Union Health Law: Themes and Implications (CUP 2015)

14. Klarić M i Nikolić M, 'Ustrojstvo javnih službi u Europskom pravnom poretku' (2011) 48(1) Zbornik radova Pravnog fakulteta u Splitu 89

15. Lear J, Mossialos E and Karl B, 'EU competition law and health policy' in Mossialos E and others (eds), Health Systems Governance in Europe The Role of European Union Law and Policy (CUP 2010)

16. Louri V, 'The FENIN Judgment: The Notion of Undertaking and Purchasing Activity' (2005) 32 Legal Issues of Economic Integration 87

17. Mijatović N, 'Sustav socijalnog osiguranja i problemi njegova financiranja' (2006) 56 Zbornik Pravnog fakulteta u Zagrebu 1607

18. Monti G, EC Competition Law (CUP 2007)

19. Odudu O, 'Are State-owned health-care providers undertakings subject to competition law? ' (2011) 48 European Competition Law Review 231

20. Poščić A, 'Pojam poduzetnika u europskom pravu tržišnog natjecanja' (2008) 29(2) Zbornik Pravnog fakulteta Sveučilišta u Rijeci 917

21. Poščić A, 'Zabranjeni sporazumi u europskom pravu tržišnog natjecanja' (2011) 32 Zbornik Pravnog fakulteta Sveučilišta u Rijeci 319

22. Puljiz M, 'Dobrovoljno zdravstveno osiguranje' u Vehovec M (ed), O zdravstvu iz ekonomske perspektive (Ekonomski institut 2014) 
23. Sauter W, 'Services of general economic interest and universal service in EU law' (2008) TILEC Discussion Paper No 2008-017 <https://papers.ssrn.com/sol3/papers.cfm?abstract_id=1136105> pristupljeno 16. srpnja 2021.

24. Sokol T i Staničić F, 'Pravni položaj Katoličke Crkve kao gospodarskog subjekta u pravu Europske unije i hrvatskom pravu' (2018) 68 Zbornik Pravnog fakulteta u Zagrebu 31

25. Sokol T i Staničić F, 'Usluge od općeg gospodarskog interesa u pravu Europske unije i hrvatski regulatorni okvir u odabranim upravnim područjima' (2019) 69 Zbornik Pravnog fakulteta u Zagrebu 803

26. Townley C, "The Concept of an "Undertaking": The Boundaries of the Corporation - A Discussion of Agency, Employees and Subsidiaries' in Amato G and Ehlermann CD (eds), EC Competition Law: A Critical Assesment (Hart Publishing 2007)

\section{PROPISI I DOKUMENTI}

1. Direktiva 2009/138/EZ Europskog parlamenta i Vijeća od 25. studenoga 2009. o osnivanju i obavljanju djelatnosti osiguranja i reosiguranja (Solventnost II) (2009) OJ L335/1

2. Direktiva 73/239/EEZ Prva direktiva Vijeća od 24. srpnja 1973. o usklađivanju zakona i drugih propisa koji u odnosu na osnivanje i obavljanje poslova izravnog osiguranja osim životnog osiguranja (1973) OJ L228/3

3. Vlada Republike Hrvatske 'Prijedlog Zakona o izmjenama i dopuni Zakona o dobrovoljnom zdravstvenom osiguranju, s Konačnim prijedlogom zakona' (Hrvatski sabor PZ br. 934) <www.sabor.hr/ sites/default/files/uploads/sabor/2020-04-23/180002/PZ_934.pdf > pristupljeno 16. srpnja 2021.

4. Obavijest Komisije o pojmu državne potpore iz članka 107. stavka 1. Ugovora o funkcioniranju Europske unije (2016) OJ C262/01

5. Obavijest Komisije o primjeni pravila o tržišnom natjecanju na poštanski sektor i o ocjeni određenih državnih mjera u vezi s poštanskim uslugama (1998) OJ C39/02

6. Odluka o cijeni police dopunskog zdravstvenog osiguranja (NN 118/2013) (HR)

7. Odluka o načinu osiguravanja i raspolaganja sredstvima dopunskog zdravstvenog osiguranja (NN 91/2013) (HR)

8. Pravila uspostavljanja i provođenja dopunskog zdravstvenog osiguranja (NN 91/2013, 136/2013, 21/2014, 135/2014, 144/2014, 42/2018) (HR)

9. Pravilnik o postupku i načinu davanja suglasnosti za obavljanje poslova dobrovoljnog zdravstvenog osiguranja (NN 112/2006, 38/2008) (HR)

10. Pravilnik o postupku, uvjetima i načinu utvrđivanja prava na plaćanje premije dopunskog zdravstvenog osiguranja iz državnog proračuna (NN 156/2008, 88/2010, 31/2016, 116/2017, 106/2018, 65/2020) (HR)

11. Pravilnik o uvjetima i načinu provođenja dopunskog zdravstvenog osiguranja (NN 2/2009, 123/2009) (HR)

12. Zakon o dobrovoljnom zdravstvenom osiguranju (NN 85/2006, 150/2008, 71/2010, 53/2020) (HR)

13. Zakon o doprinosima (NN 84/2008, 152/2008, 94/2009, 18/2011, 22/2012, 144/2012, 148/2013, 41/2014, 143/2014, 115/2016, 106/2018) (HR)

14. Zakon o obveznim odnosima (NN 35/2005, 41/2008, 125/2011, 78/2015, 29/2018) (HR)

15. Zakon o obveznom zdravstvenom osiguranju (NN 80/2013, 137/2013, 98/2019) (HR) 
16. Zakon o obveznom zdravstvenom osiguranju i zdravstvenoj zaštiti stranaca u Republici Hrvatskoj (NN 80/2013, 15/2018) (HR)

17. Zakon o osiguranju (NN 30/2015, 112/2018, 63/2020) (HR)

18. Zakon o zdravstvenem varstvu i zdravstvenem zavarovanju (UL 9/1992, 72/2006, 114/2006, 91/2007, 135/2014, 76/2008, 62/2010, 87/2011, 40/2012. 21/2013, 91/2013, 99/2013, 111/2013, 95/2014, 47/2015, 61/2017, 64/2017, 36/2019) (SI)

\section{PRESUDE I DRUGE ODLUKE}

1. Case C-158/96 Raymond Kohll v Union des caisses de maladie (1998) ECR I-01931

2. Case C-205/03 P Federación Española de Empresas de Tecnología Sanitaria (FENIN) v Commission of the European Communities (2006) ECR I-6295

3. Case C-244/94 Fédération Française des Sociétés d'Assurance, Société Paternelle-Vie, Union des Assurances de Paris-Vie and Caisse d'Assurance et de Prévoyance Mutuelle des Agriculteurs v Ministère de l'Agriculture et de la Pêche (1995) ECR I-4013

4. Case C-280/00 Altmark Trans GmbH and Regierungspräsidium Magdeburg v Nahverkehrsgesellschaft Altmark $\mathrm{GmbH}$, and Oberbundesanwalt beim Bundesverwaltungsgericht (2003) ECR I-7747

5. Case C-41/90 Klaus Höfner and Fritz Elser v Macrotron GmbH (1991) ECR I-1979

6. Case C-437/09 AG2R Prévoyance v Beaudout Père et Fils SARL (2011) ECR I-973

7. Case C-475/99 Ambulanz Glöckner v Landkreis Südwestpfalz (2001) ECR I-8089

8. Case T-289/03 British United Provident Association Ltd (BUPA), BUPA Insurance Ltd and BUPA Ireland Ltd $v$ Commission of the European Communitie (2008) ECR II-81

9. Case T-319/99 Federación Nacional de Empresas de Instrumentación Científica, Médica, Técnica y Dental (FENIN) v Commission of the European Communities (2003) ECR II-357

10. Commission Decision of 20 March 2001 relating to a proceeding under Article 82 of the EC Treaty (Case COMP/35.141 — Deutsche Post AG) Commission Decision 2001/354/EC (2001) OJ L125/27

11. Joined Cases C-159/91 and C-160/91 Christian Poucet v Assurances Générales de France and Caisse Mutuelle Régionale du Languedoc-Roussillon (1993) ECR I-637

12. Joined Cases C-180/98 and C-184/98 Pavel Pavlov and Others v Stichting Pensioenfonds Medische Specialisten (2000) ECR I-6451

13. Joined Cases C-264/01, C-306/01, C-354/01 and C-355/01 AOK Bundesverband, Bundesverband der Betriebskrankenkassen (BKK), Bundesverband der Innungskrankenkassen, Bundesverband der landwirtschaftlichen Krankenkassen, Verband der Angestelltenkrankenkassen eV, Verband der Arbeiter-Ersatzkassen, Bundesknappschaft and See-Krankenkasse v Ichthyol-Gesellschaft Cordes, Hermani \& Co. (C-264/01), Mundipharma GmbH (C-306/01), Gödecke GmbH (C-354/01) and Intersan, Institut für pharmazeutische und klinische Forschung GmbH (C-355/01) (2004) ECR I-2493 


\section{THE EU COMPETITION AND STATE AID RULES AND COMPLEMENTARY HEALTH INSURANCE IN THE REPUBLIC OF CROATIA: WHAT WENT WRONG?}

\section{Summary}

Competition and state aid rules are not applicable to compulsory health insurance in the Republic of Croatia, since the latter does not constitute an economic activity as defined by EU law. On the other hand, complementary health insurance, as established in Croatia, constitutes an economic activity, due to the existence of real competition between undertakings. The illustrated situation with competition in complementary health insurance market allows for the statement that special rules applicable to Croatian Health Insurance Fund (HZZO) provide the latter with a privileged position when compared to its private competitors to whom these rules do not apply. Moreover, this privileged position is strengthened by the fact that HZZO, as a legal monopolist within the sphere of compulsory health insurance, utilizes respective infrastructure in the field of complementary health insurance, which enables it to reduce expenses to the detriment of its private competitors lacking such a privilege.

A solution for the described situation could be for the state to establish a separate entity to provide complementary health insurance. This entity would have to provide open enrolment and community rating, regardless of age, sex or health of the insured persons. In order to prevent private competitors from jeopardising the exercise of service of general economic interest by taking over only the insured persons with a more favourable risk profile, a risk equalisation scheme would have to be set up. This would result in a transfer of funds from insurers with a favourable risk profile to those with an unfavourable risk profile on basis of objective and clear criteria, thereby making it possible for the latter to provide service to the higher-risk insured persons like the elderly and the ones with chronic illnesses. In this way, a balance between the necessity to provide a service of general economic interest to all insured persons, including those with a higher risk, and competition on the EU internal market, would be struck.

Keywords: $\quad$ complementary health insurance, state aid, competition, proportionality, services of general economic interest Economics and Management, Vukasovićeva ulica 1, 10000 Zagreb. E-mail address: tsokol12@gmail.com. ORCID: https://orcid. org/0000-0002-3592-2967.

** Frane Staničić, PhD, Associate Professor, Faculty of Law, University of Zagreb, Trg Republike Hrvatske 14, 10000 Zagreb. E-mail address: frane.stanicic@pravo.hr. ORCID: https://orcid.org/0000-0001-8304-7901. 